\title{
Herbal Anti-Hyperglycemic Compound Improves Glycemic Control and Insulin Sensitivity in Diabetic Rats
}

\author{
Aiman A Jafri ${ }^{1}$, Suman B Sharma ${ }^{1 *}$, Usha R Singh ${ }^{2}$, Kalpana Luthra ${ }^{3}$ \\ ${ }^{1}$ Department of Biochemistry, University College of Medical Sciences (University of Delhi), Dilshad Garden, Delhi, India \\ ${ }^{2}$ Department of Pathology, University College of Medical Sciences (University of Delhi), Dilshad Garden, Delhi, India \\ ${ }^{3}$ Department of Biochemistry, All India institute of Medical Sciences, Ansari Nagar, New Delhi
}

*Corresponding author: Suman, B. Sharma, Department of Biochemistry, University College of Medical Sciences (University of Delhi), Dilshad Garden, Delhi- 110095, Tel: +91-9818041119; E-mail: drsbs08@hotmail.com

\begin{abstract}
Objective: To study the effect of HPLC purified herbal anti-hyperglycemic active compound (FIIc) isolated from the fruit pulp of Eugenia jambolana in diabetic rats.

Methods: 24 male wistar rats were taken and diabetes was induced in group B, C and $\mathrm{D}$ rats $(\mathrm{n}=6 \mathrm{each})$ by injecting Streptozotocin at a dose of $45 \mathrm{mg} / \mathrm{kg}$ of body weight 15 minutes after Nicotinamide at a dose $230 \mathrm{mg} / \mathrm{kg}$ body weight intraperitoneally after overnight fasting. Active compound (FIIc) was given to group C and Pioglitazone to group D at dose of $20 \mathrm{mg} / \mathrm{kg}$ of body weight orally for 4 weeks respectively. Glycemic and lipid profile, protein tyrosine kinase activity and serum DPP-4 levels were measured and compared between all the 4 study groups.

Results: Significant Improvement in body weight, glycemic profile, dyslipidemia and tyrosine kinase activity $(4.90 \pm 1.28 \mathrm{U} / \mathrm{mg}$ protein) were observed in FIIc treated rats at week 4 of the study compared to diabetic control rats. Serum DPP-4 levels $(26.41 \pm 0.43$ $\mathrm{pg} / \mathrm{ml}$ ) were also found to be decreased in FIIc treated rats at week 4 of the study compared to diabetic control rats. This is possibly due to increased serum insulin levels and increased insulin sensitivity after treatment with active compound FIIc.

Conclusion: FIIc significantly reduced hyperglycemia and dyslipidemia by inhibiting DPP-4 levels and improves insulin sensitivity by increasing protein tyrosine kinase activity and serum insulin levels.
\end{abstract}

Received date: April 13, 2016

Accepted date: June 30, 2016

Published date: July 05, 2016

Citation: Sharma, S.B., et al. Herbal Anti-Hyperglycemic Compound Improves Glycemic Control and Insulin Sensitivity in Diabetic Rats. (2016) J Diabetes Obes 3(1): 27-32.

DOI: $10.15436 / 2376-0494.16 .864$

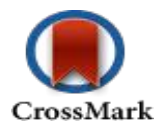

Keywords: Eugenia jambolana; FIIc; Diabetes; Tyrosine kinase; Dipeptidyl Peptidase 4; Pioglitazone; Wistar rats; HPLC

\section{Introduction}

Type 2 Diabetes mellitus is a disorder of carbohydrate metabolism which is characterized by a combination of peripheral insulin resistance and impaired insulin secretory capacity of pancreatic beta cell. In due course of time when it is unable to maintain sufficient hyper-insulinemic response, overt diabetes ensues. Modern synthetic medicines have several side effects compared to herbal drugs, due to which the popularity of traditional and complimentary medicines has increased ${ }^{[1]}$.

The anti-hyperglycemic activity of Eugenia jambolana (Botanical name- Syzgium cumini) from its seeds, fruit pulp, bark and roots has been well established ${ }^{[2-5]}$. It has also known to have several anti diabetic compounds such as ferulic acid, cuminoside, $\alpha$-hydroxy succinamic acid, stigma sterol, $\beta$-sitosterol, lupeol, ellagic acid, gallic acid, quercetin and kempferol ${ }^{[6]}$. Attenuation of renal dysfunction by anti-hyperglycemic compound isolated from fruit pulp of Eugenia jambolana in Streptozotocin-induced diabetic rats has also been reported ${ }^{[7]}$. The fruit extract $(250 \mathrm{mg} / \mathrm{kg})$ lowered glucose in overnight fasted streptozotocin induced diabetic rats; the treatment increased glycogen content in liver, induced degranulation in $\beta$-cells. The fruit may stimulate insulin secretion. The water extract of the fruit pulp also showed anti-hyperglycemic activity in normal and alloxan-induced diabetic rats ${ }^{[8]}$.

Sharma et al has already isolated the active antihyperglycemic compound known as alpha hydroxy succinamic acid (FIIc) (US Patent number 6,426,826 dated 6th August 2002; Indian Product Patent number. 2,30,753 February 2009) from the fruit pulp of Eugenia jambolana $^{[8]}$. 
Incretin hormones such as GLP 1 and GIP have shown to control post prandial glucagon release, delay gastric emptying and increase satiety ${ }^{[9,10]}$. It has also been reported to stimulate insulin secretion ${ }^{[1,12]}$, stimulate beta cells proliferation and differentiation $^{[13,14]}$. However, GLP 1 has a very short half-life. It is rapidly degraded inside our body by the enzyme Dipeptidyl Peptidase 4 (DPP-4). Therapeutic agents that can block the DPP-4 enzyme (DPP-4 inhibitors) can increase the endogenous GLP-1 level and thus enhances the incretin action. Dipeptidyl Peptidase inhibitors, which act via enhancing the incretins represents another new therapeutic approach for the treatment of type 2 diabetes.

Glucose uptake in peripheral tissues is also stimulated by Insulin receptor tyrosine kinase and under pathologic conditions may result in a range of clinical manifestations including diabetes ${ }^{[15,16]}$. In a recent study it was shown that when non-obese diabetic mouse treated with tyrosine kinase inhibitors showed improved glycemic control and increased insulin sensitivity ${ }^{[17,18]}$. Hence, the development of tyrosine kinase inhibitors offers increasing opportunities for the treatment of various diseases including diabetes.

The present study was therefore planned to evaluate the effect of purified active principle (FIIc) on Streptozotocin-Nicotinamide induced diabetic rats and to ascertain its mechanism of action by evaluating its effect on DPP-4 levels and tyrosine kinase activity.

\section{Material and Methods}

\section{Isolation and purification of active anti-hyperglycemic compound (FIIc)}

Preparation of crude aqueous extract: Fresh fruit pulp of Eugenia jambolana was grinded in a mixer grinder with distilled water $(500 \mathrm{~mL})$. After filtration through muslin cloth, the filtrate was centrifuged at $10,000 \mathrm{rpm}$ at $4^{\circ} \mathrm{C}$ and then lyophilized to store it for a longer duration. The yield of lyophilized water extract was about $10 \mathrm{~g}$ from $650 \mathrm{~g}$ of fruit pulp, which was obtained from $1 \mathrm{~kg}$ fruits of E. jambolana.

Ion exchange chromatography was carried out for the isolation and purification of active compound (FIIc) using diethyl amino ethyl cellulose- 52 (DEAE-52) as the stationary phase. Fractions were then eluted with $0.1 \mathrm{M}$ phosphate buffer (pH 6.0). A total of four fractions (FI to FIV) were obtained out of which FII has the significant high anti-hyperglycemic activity among the four fractions. FII was again subjected to Ion exchange chromatography and active compound (FIIc) was obtained. The US and Indian patents have already been granted $^{[8]}$.

Chemical characterization of active compound (FIIc): Homogeneity of FIIc was confirmed by HPL-C which gave a single peak after employing it on chromolith column (chromolith performance HPL-C column RP-18e $100-4.6 \mathrm{~mm}$ ). FIIc was eluted with mobile phase (Water : Methanol : Acetonitrile :: $70: 15: 15$ ) and monitored by PDA detector at wavelength $220 \mathrm{~nm}$ (Instrument Shimadzu HPL-C model SPD-M20A). A single peak was observed in chromatogram, suggesting that FIIc was almost homogenous as demonstrated in previous studies done by Sharma et al ${ }^{[8]}$.

Experimental animals: Male Wistar albino rats (weighing 220 - 250 grams) were procured from Central Animal House of University College of Medical Sciences (UCMS), University of Delhi, India. The animals were housed in standard conditions of temperature $\left(22 \pm 2^{\circ} \mathrm{C}\right)$ and at 12 hour light-dark cycle. The rats were fed with commercial diet (Hindustan liver Ltd., Mumbai) and water ad libitum. The experimental protocol was approved by the Institutional Animal Ethical Committee (IAEC), UCMS, Delhi, India (UCMS/IAEC/26 granted on $30^{\text {th }}$ December 2009).

Induction of diabetes: To induce diabetes, a freshly prepared solution of streptozotocin $(45 \mathrm{mg} / \mathrm{kg}$ of body weight in $0.1 \mathrm{M}$ citrate buffer, $\mathrm{pH} 4.5$ ) was injected intraperitoneally to overnight fasted rats. Nicotinamide at a dose of $230 \mathrm{mg} / \mathrm{kg}$ body weight was given 15 minutes prior to STZ injection for the development of stable type 2 diabetes mellitus ${ }^{[19]}$. After 48 hours of STZ administration, fasting blood glucose (FBG) levels were measured.

Study design: Male Wistar rats were taken for the present study and divided into following groups (6 rats each group).

Group A: Healthy control (normal saline)

Group B: Diabetic control (normal saline)

Group C: Diabetic treated with FIIc (20 mg/kg of body weight)

Group D: Diabetic treated with Pioglitazone ( $20 \mathrm{mg} / \mathrm{kg}$ of body weight)

Animals in group A and B were given standard chow diet. Purified active compound (FIIc) was given orally to group C at a dose of $20 \mathrm{mg} / \mathrm{kg}$ of body weight day for 4 weeks, which is the effective dose of FIIc standardized in previous studies done by Sharma et al ${ }^{[8]}$. Pioglitazone was given as a standard drug orally at a dose of $20 \mathrm{mg} / \mathrm{kg}$ of body weight /day for 4 weeks to group D. An equal volume of vehicle was given to healthy control group A and diabetic untreated group B.

Glycemic parameters and hormonal assays: Blood was drawn from retro orbital plexus by using micro-capillary technique from all overnight fasted animals on day 1 and afterwards at week 4 of the study. Whole blood was drawn for the estimation of Glycosylated hemoglobin and plasma was separated from blood for the estimation of Glucose. Serum was separated for the estimation of lipids, Insulin and Dipeptidyl Peptidase-4. These samples were carefully processed and stored in $-80^{\circ} \mathrm{C}$ deep freezer. These parameters were measured using commercially available kits: plasma glucose (Fortress diagnostics, United Kingdom), HbA1c (For- 
FIIc Improves Insulin Sensitivity in Diabetic Rats

tress diagnostics, United Kingdom), total serum cholesterol (Fortress diagnostics, United Kingdom), serum triglycerides (Fortress diagnostics, United Kingdom), HDL-C (Fortress diagnostics, United Kingdom), Insulin (Mercodia rat ELISA kit, Sweden), tyrosine kinase (Bio medical Assay rat ELISA kit, China) and DPP-4 (Bioassay technology laboratory rat ELISA kit, China) respectively. Each time quality control sera (Bio-Rad, USA) were run along with the samples. Results of the unknown sample and quality control sera were reproducible.

Insulin Receptor (IR)-binding assay: After 4 weeks of treatment rats were sacrificed and their organs including liver and adipose tissues were dissected for the estimation of protein tyrosine kinase activity. These tissues were collected and solubilized by lysis buffer. IR-binding assay was performed using Rayto 2100c microplate ELISA reader (Rayto, China). The amount of phosphorylated IR was quantified by sandwich enzyme-linked immunosorbent assay (ELISA). The absorbance was measured at $450 \mathrm{~nm}$ through ELISA plate reader.

Statistical analysis: Two way ANOVA was applied for the comparison of parameters between the groups followed by Tukey's test. Pearson's coefficient of correlation was calculated for all the 3 groups together and separately for all the above mentioned parameters. Difference was assumed to be significant at the level of $\mathrm{p}<0.05$.

\section{Results}

\section{Effect of FIIc on glycemic index}

In the present study a significant improvement was observed in body weight, glycemic and lipid profile in FIIc treated rats at week 4 of the study compared to diabetic controls. Serum insulin and HDL-C were found to be significantly increased in FIIc treated rats at week 4 of the study compared to diabetic controls (Table 1).

Table 1: Showing body weight, glycemic, lipid and hormonal profile at week 0 and at week 4 after treatment with FIIc and Pioglitazone.

\begin{tabular}{|c|c|c|c|c|c|}
\hline Glycemic and lipid parameters & Time points & Group A & Group B & Group C & Group D \\
\hline \multirow{2}{*}{$\begin{array}{l}\text { Body } \\
\text { Weight }\end{array}$} & Week 0 & $222.5 \pm 5.89$ & $221.67 \pm 9.83$ & $229.17 \pm 9.70$ & $245 \pm 27.20$ \\
\hline & Week 4 & $254.33 \pm 31.97$ & $218.5 \pm 11.14^{\mathrm{a}}$ & $236.67 \pm 7.06^{\mathrm{b}}$ & $251.67 \pm 28.32$ \\
\hline \multirow{2}{*}{$\begin{array}{l}\text { FBG } \\
(\mathrm{mmol} / \mathrm{l})\end{array}$} & Week 0 & $4.92 \pm 0.037$ & $10.41 \pm 0.032$ & $10.54 \pm 0.048$ & $10.1 \pm 0.075$ \\
\hline & Week 4 & $4.68 \pm 0.059$ & $12.53 \pm 0.068$ & $8.47 \pm 0.063$ & $8.16 \pm 0.058$ \\
\hline \multirow{2}{*}{$\begin{array}{l}\text { HbA1c } \\
\%\end{array}$} & Week 0 & $5.1 \pm 0.12$ & $5.3 \pm 0.12^{\mathrm{a}}$ & $5.31 \pm 0.22 \mathrm{~b}$ & $5.36 \pm 0.29^{\mathrm{c}, \mathrm{e}}$ \\
\hline & Week 4 & $5.13 \pm 0.10$ & $8.58 \pm 0.91^{\mathrm{a}}$ & $5.38 \pm 0.17^{\mathrm{b}, \mathrm{d}}$ & $5.33 \pm 0.26^{\mathrm{c}, \mathrm{e}}$ \\
\hline \multirow{2}{*}{$\begin{array}{l}\text { Serum TG } \\
(\mathrm{mg} / \mathrm{dl})\end{array}$} & Week 0 & $64.33 \pm 4.45$ & $66.5 \pm 7.58$ & $64.17 \pm 5.6$ & $65.17 \pm 7.52$ \\
\hline & Week 4 & $67.00 \pm 6.29$ & $114.00 \pm 6.29^{\mathrm{a}}$ & $92.00 \pm 4.8^{\mathrm{b}, \mathrm{d}}$ & $87.00 \pm 4.51 \mathrm{c}, \mathrm{e}$ \\
\hline \multirow{2}{*}{$\begin{array}{l}\text { Total CHL } \\
\text { (mg/dl) }\end{array}$} & Week 0 & $67.16 \pm 4.91$ & $64.17 \pm 9.92$ & $69.33 \pm 5.31$ & $66.67 \pm 2.50$ \\
\hline & Week 4 & $67.5 \pm 4.32$ & $98 \pm 7.26^{\mathrm{a}}$ & $76 \pm 6.57^{d}$ & $73 \pm 7.3^{\mathrm{e}}$ \\
\hline \multirow{2}{*}{$\begin{array}{l}\text { HDL-C } \\
(\mathrm{mg} / \mathrm{dl})\end{array}$} & Week 0 & $38.17 \pm 1.60$ & $37.33 \pm 1.50$ & $37.67 \pm 1.50$ & $37.67 \pm 1.63$ \\
\hline & Week 4 & $38 \pm 1.09$ & $25.17 \pm 1.16^{\mathrm{a}}$ & $34 \pm 1.09^{\mathrm{b}, \mathrm{d}}$ & $34.5 \pm 1.04^{\mathrm{c}, \mathrm{e}}$ \\
\hline \multirow{2}{*}{$\begin{array}{l}\text { LDL-C } \\
\text { (mg/dl) }\end{array}$} & Week 0 & $16.13 \pm 5.09$ & $13.53 \pm 9.59$ & $18.83 \pm 6.62$ & $15.97 \pm 3.11$ \\
\hline & Week 4 & $16.1 \pm 3.19$ & $50.03 \pm 7.92^{a}$ & $23.60 \pm 7.08^{d}$ & $21.10 \pm 7.57^{\mathrm{e}}$ \\
\hline \multirow{2}{*}{$\begin{array}{l}\text { DPP-4 } \\
\text { (pg/ml) }\end{array}$} & Week 0 & $32.7 \pm 0.62$ & $32.43 \pm 0.56$ & $32.43 \pm 0.71$ & $32.56 \pm 0.50$ \\
\hline & Week 4 & $32.40 \pm 0.67$ & $34.53 \pm 0.48$ & $26.41 \pm 0.43^{\mathrm{b}, \mathrm{d}}$ & $37.61 \pm 4.49$ \\
\hline \multirow{2}{*}{$\begin{array}{l}\text { Serum Insulin } \\
\text { (pmol) }\end{array}$} & Week 0 & $16.18 \pm 0.59$ & $9.1 \pm 0.58^{\text {a }}$ & $9.00 \pm 0.34^{\mathrm{b}, \mathrm{d}}$ & $9.08 \pm 0.24^{\mathrm{c}, \mathrm{e}}$ \\
\hline & Week 4 & $16.30 \pm 0.29$ & $7.36 \pm 0.19^{\mathrm{a}}$ & $12.00 \pm 0.44^{\mathrm{b}, \mathrm{d}}$ & $12.45 \pm 0.35^{\mathrm{c}, \mathrm{e}}$ \\
\hline Liver Tyrosine kinase (U/mg protein) & Week 4 & $12.11 \pm 0.85$ & $2.18 \pm 0.86^{\mathrm{a}}$ & $4.90 \pm 1.28^{\mathrm{b}, \mathrm{d}}$ & $5.31 \pm 0.51^{\mathrm{ce} e}$ \\
\hline $\begin{array}{l}\text { Adipose Tyrosine kinase (U/mg } \\
\text { protein) }\end{array}$ & Week 4 & $10.26 \pm 0.28$ & $1.63 \pm 0.24^{\mathrm{a}}$ & $3.21 \pm 0.34^{\mathrm{b}, \mathrm{d}}$ & $4.38 \pm 0.51^{\mathrm{c}, \mathrm{e}}$ \\
\hline
\end{tabular}

Values are mean \pm S.D. $(n=6) .(p<0.001)$

$\mathrm{a}=$ group A vs. Group B, b = Group A vs. Group C, c = Group A vs. Group D, d = Group B vs. Group C, e = Group B vs. Group D.

\section{Effect of FIIc on tyrosine kinase activity}

After treatment with active compound (FIIc), we have observed $55.5 \%$ and $49.22 \%$ increase in tyrosine kinase activity in liver and adipose tissues respectively compared to the diabetic controls rats at week 4 of the study. Group D rats treated with Pioglitazone also demonstrated $58.94 \%$ and $62.7 \%$ increase in tyrosine kinase activity in liver and adipose tissues respectively compared to the diabetic controls (Table 1). 


\section{Effect of FIIc on serum DPP 4 levels}

As indicated from table 1, the baseline values of serum DPP-4 levels were found to be similar between the various study groups. But on week 4 of the study we observed a $(p<0.001)$ significant decrease in serum DPP-4 levels in group C compared to group B rats. FIIc treated rats demonstrated an $18.56 \%$ decrease in serum DPP-4 levels at week 4 of the study compared to baseline levels while no decrease was observed in DPP-4 levels in Pioglitazone treated group D rats.

\section{Discussion}

In the present study, we studied the effect of HPL-C purified active compound FIIc isolated from the fruit pulp of Eugenia jambolana in animal model of diabetes on various glycemic, lipid, hormonal parameters and the activity of protein tyrosine kinase after 4 weeks of treatment.

Due to the partial destruction of pancreatic beta cells, we observed decreased serum Insulin levels and tyrosine kinase levels in diabetic control rats compared to healthy controls (Table 1). After treatment with active compound FIIc for 4 weeks we observed a significant increase in serum insulin levels and activity of protein tyrosine kinase in liver and adipose tissue homogenates of FIIc treated rats compared to diabetic controls (Table 1). Reduced tyrosine kinase activity in diabetes has been reported in previous studies ${ }^{[15,16]}$. This decrease in tyrosine kinase activity is may be due to hyperglycemia which activates protein kinase $\mathrm{C}$ leading to production of insulin receptor with phosphorylated serine residue which in turn may prevent subsequent beta subunit tyrosine phosphorylation ${ }^{[2,21]}$. Reduced insulin level also leads to decreased binding of insulin to its tyrosine kinase receptors which ultimately caused increased blood glucose levels. Insulin stimulates the increased uptake of glucose through increased binding of insulin to its tyrosine kinase receptors. Insulin also causes increase in activity of protein tyrosine kinase through phosphorylation of beta subunit and decrease in protein kinase $\mathrm{C}$ activity. Animal studies have also reported beneficial effects of Cinnamon extract, a traditional herb on serum insulin levels and tyrosine phosphorylation ${ }^{[2]}$. After treatment with Cinnamon extract, the author has reported a significant increase in glucose infusion rate at $3 \mathrm{mU} / \mathrm{kg}$ per min Insulin infusion compared with healthy controls. It was suggested that the cinnamon extract potentiated increased glucose uptake via enhancing the insulin signaling pathway ${ }^{[22]}$.

Studies have also reported that treatment with tyrosine kinase inhibitors leads to reduction in insulin requirements and improved glycemic control in diabetes ${ }^{[23-25]}$. Lo et al. has demonstrated in Taiwanese population the beneficial effects of traditional Chinese medicinal formula in type 2 diabetes ${ }^{[26]}$. It has been reported to ameliorates glycemic index and impaired insulin secretion via phosphatidylinositide 3-kinase (PI3K)/Akt pathway in diabetic animals ${ }^{[26]}$. He proposed that the herbal drug CYSKT increased the amount of phosphorylated IR and stimulated the translocation of GLUT-4 to cell membrane and suggested that CYSKT might bind to IR, which in turn activate the phosphorylation of IR, and stimulate the down-stream signaling pathway. In his previous study, it has also been reported that a protein component from Momordica charantia binds to IR, activates the insulin signaling pathway, and lowers the blood glucose levels in diabetic mice ${ }^{[27]}$. Similar findings have also been reported by Zhao et al ${ }^{[28]}$. Our results are in consonance with previous studies which also shows that the herbal treatment improves tyrosine kinase activity leading to improved glycemic profile.

In our study we have also observed a significant decrease in serum DPP-4 levels in FIIc treated rats compared to diabetic controls. Studies have reported dysregulated serum DPP-4 levels during diabetic conditions ${ }^{[29]}$. DPP-4 inhibition by active compound FIIc resulted in increased incretin levels which in turn stimulated beta cells leading to increased insulin levels as reflected by our results at week 4 of the study (table 1). Histopathology of pancreases also showed increased Beta cell islets in FIIc treated (Figure 1) rats compared to diabetic controls (Figure 2). Our results are also supported by previous studies as GLP-1 has been reported to maintain glucose homeostasis and increase insulin secretion in glucose dependent manner ${ }^{[30,31]}$. Administration of, GLP-1 and its analogs have also shown beneficial glucose lowering effects in diabetic subjects ${ }^{[32]}$ and in animal model of diabetes ${ }^{[3,34]}$. Studies have also reported that these agents were known to have beneficial effects on islets neogenesis, beta cell survival and differentiation $^{[35.36]}$. Previous studies have also reported that elevated levels of circulating GLP-1 and GIP were observed in DPP 4 deficient mice which are resistant to STZ-induced beta cell destruction ${ }^{[37,38]}$. Also GLP-1 treatment has been reported to prevent streptozotocin induced beta cell apoptosis ${ }^{[39,40]}$. Studies have also reported that mice lacking both GLP-1 and GIP receptors clearly demonstrate that these incretins are acutely responsible for DPP 4 inhibition and glycemic controls ${ }^{[41]}$. A study by Zhang et al. reported that alogliptin restored the $\beta$-cell mass and islet morphology, and increased insulin secretion in their diabetic mouse model induced by STZ treatment $^{[42]}$. Similar results were reported by Ahren and Hughes ${ }^{[43]}$.

Increased serum insulin levels is also responsible for increased uptake of triglycerides from the blood into the muscles and adipose tissues, decreased rate of lipolysis in adipose tissues therefore lowers plasma fatty acid levels ${ }^{[44]}$. Hence we observed increased body weight and improved glycemic profile in FIIc treated rats compared to diabetic controls (Table 1). Rats treated with Pioglitazone also demonstrated similar results as it is known to have insulin sensitizing properties resulting in improved glycemic index and lipid profile.

Hence we conclude that purified active compound (FIIc) isolated from the fruit pulp of Eugenia jambolana has significant effect on glycemic control, serum lipid profile and insulin sensitivity. It also significantly decreased serum DPP-4 levels and improves the altered levels of protein tyrosine kinase which is involved in establishing a smooth insulin signaling mechanism. 


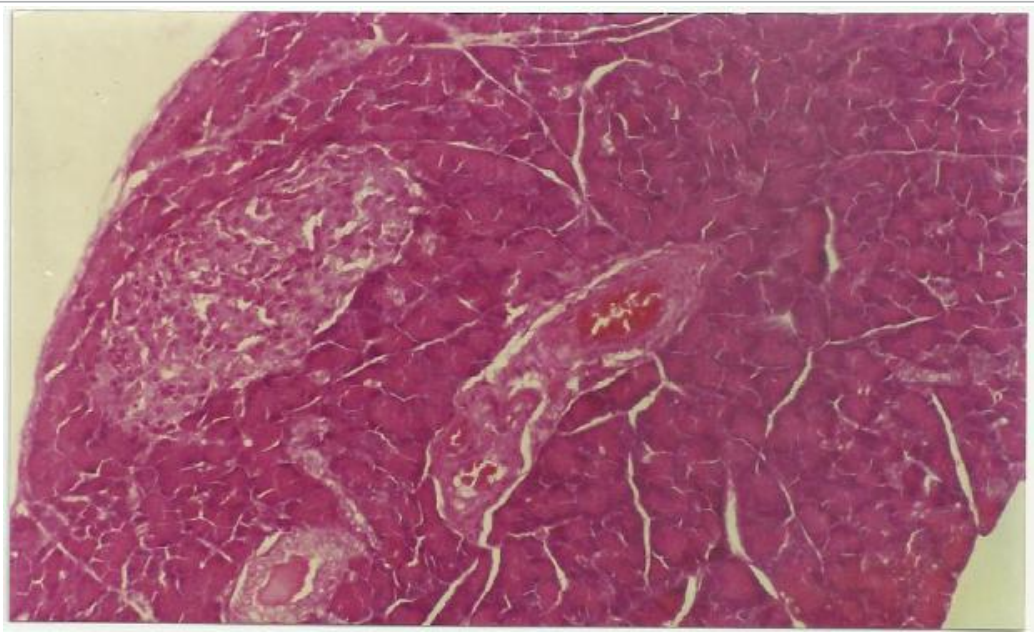

Figure 1: Showing regenerated Islets of pancreatic beta cell mass after treatment with active compound FIIc in group C rats at week 4 of the study.

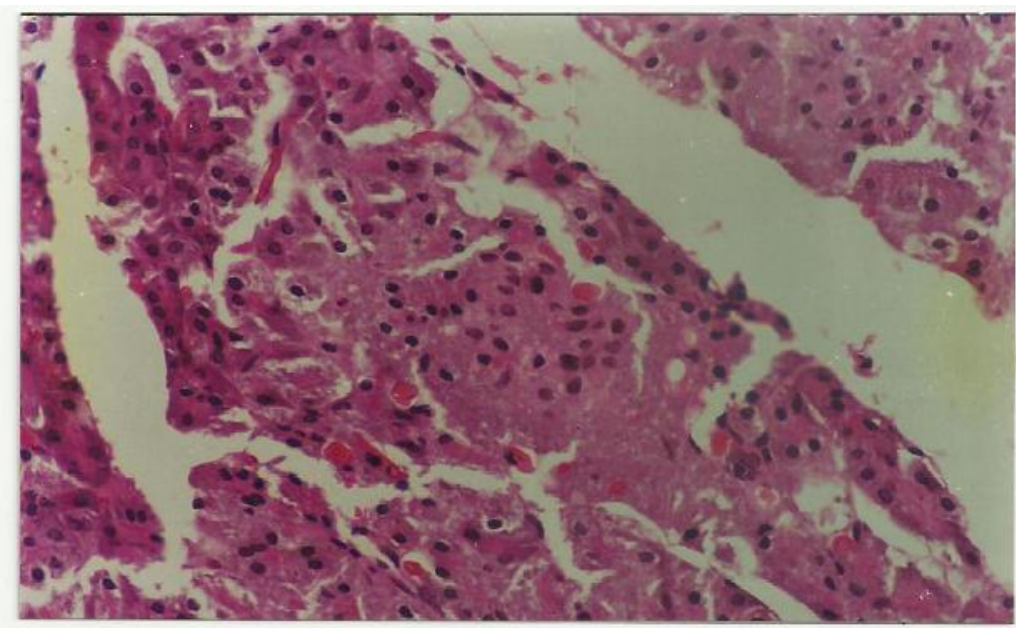

Figure 2: Showing Streptozotocin-NAD induced degenerated Islets of pancreatic beta cell mass in group B rats at week 4 of the study.

\section{Conclusion}

Thus FIIc significantly reduces hyperglycemia, hyperlipidemia via inhibiting serum DPP-4 levels and improves serum insulin and tyrosine kinase activity, and it may prove potential herbal compound for the management of type 2 diabetes.

Acknowledgements: The authors acknowledge Indian Council of Medical Research, New Delhi for their financial support.

Conflict of Interests: The authors declare that they have no conflicting interests.

\section{References}

1. Saibabu, V., Fatima, Z., Khan, L.A., et al. Therapeutic Potential of Dietary Phenolic Acids. (2015) Adv Pharmacol Sci. $2015: 823539$. doi: 10.1155/2015/823539. Epub 2015 Sep 9.

2. Sharma, S.B., Nasir, A., Prabhu, K.M., et al. Antihyperglycemic effect of the fruit-pulp of Eugenia jambolana in experimental diabetes mellitus. (2006) J Ethnopharmacol 104(3): 367-373.

3. Ravi, K., Sivagnanam, K., Subramanian, S. Anti-diabetic activity of Eugenia jambolana seed kernels on streptozotocin-induced diabetic rats. (2004) J Med Food 7(2): 187-191.

4. Rizvi, S.I., Mishra, N. Traditional Indian medicines used for the management of diabetes mellitus. (2013) J Diabetes Res $2013: 712092$.

5. Chaturvedi, A., Bhawani, G., Agarwal, P.K., et. al. Antidiabetic and antiulcer effects of extract of Eugenia jambolana seed in mild diabetic rats: study on gastric mucosal offensive acid-pepsin secretion. (2009) Indian J Physiol Pharmacol 53(2): 137-146.

6. Subramoniam A. Plants with anti diabetes properties. (2016) CRC Press.

7. Tanwar, R.S., Sharma, S.B., Singh, U.R., et al. Attenuation of renal dysfunction by anti-hyperglycemic compound isolated from fruit pulp of Eugenia jambolana in streptozotocin-induced diabetic rats. (2010) Indian J Biochem Biophys 47(2): 83-89.

8. Tanwar, R.S., Sharma, S.B., Singh, U.R., et al. Antiatherosclerotic Potential of Active Principle Isolated from Eugenia jambolana in Streptozotocin-Induced Diabetic Rats. (2011) Evid Based Complement Alternat Med 2011: 127641.

9. Flint, A., Raben, A., Astrup, A., et al. Glucagon-like peptide 1 promotes satiety and suppresses energy intake in humans. (1998) J Clin Invest 101(3): 515-520.

10. Kim, W., Egan, J.M. The role of incretins in glucose homeostasis and diabetes treatment. (2008) Pharmacol Rev 60(4): 470-512. 
11. Creutzfeldt, W. The incretin concept today. (1979) Diabetologia 16(2): 75-85.

12. Toft-Nielsen, M.B., Madsbad, S., Holst, J.J. Determinants of the effectiveness of glucagon-like peptide-1 in type 2 diabetes. (2001) J Clin Endocrinol Metab 86(8): 3853-3860.

13. Kluz, J., Adamiec, R. New therapeutic approach in patients with type 2 diabetes based on glucagon-like peptide 1 (GLP-1) and gastric inhibitory peptide (GIP). (2006) Postepy Hig Med Dosw (Online) 60: 15-23.

14. Thorens, B. Physiology of GLP-1-lessons from glucoincretin receptor knockout mice. (2004) Horm Metab Res 36(11-12): 766-770.

15. Hotamisligil, G.S., A, Budavari., D, Murray., et al. Reduced tyrosine kinase activity of the insulin receptor in obesity-diabetes. Central role of tumor necrosis factor-alpha. (1994) J Clin Invest 94(4): 1543-1549.

16. Arner, P., Pollare, T., Lithell, H., et al. Defective insulin receptor tyrosine kinase in human skeletal muscle in obesity and type 2 (non-insulin-dependent) diabetes mellitus. (1987) Diabetologia 30(6): 437-440.

17. Han, M.S., Chung, K.W., Cheon, H.G., et al. Imatinib mesylate reduces endoplasmic reticulum stress and induces remission of diabetes in db/ db mice. (2009) Diabetes 58(2): 329-336.

18. Hägerkvist, R., Sandler, S., Mokhtari, D., et al. Amelioration of diabetes by imatinib mesylate (Gleevec): role of beta-cell NF-kappaB activation and anti-apoptotic pre conditioning. (2007) FASEB J 21(2): 618-628.

19. Szkudelski, T. Streptozotocin-nicotinamide-induced diabetes in the rat. Characteristics of the experimental model. (2012) Exp Biol Med (Maywood) 237(5): 481-490.

20. Lee, T.S., Saltsman, K.A., Ohashi, H., et al. Activation of protein kinase C by elevation of glucose concentration: proposal for a mechanism in the development of diabetic vascular complications. (1989) ProcNatlAcadSci USA 86(13): 5141-5145.

21. Takayama, S., White, M.F., Kahn, C.R. Phorbol ester-induced serine phosphorylation of the insulin receptor decreased its tyrosine kinase activity. (1988) J BiolChem 263(7): 3440-3447.

22. Qin, B., Nagasaki, M., Ren, M., et al. Cinnamon extract (traditional herb) potentiates in vivo insulin-regulated glucose utilization via enhancing insulin signaling in rats. (2003) Diabetes Res Clin Pract 62(3): 139-148.

23. Huda, M.S., Amiel, S.A., Ross, P., et al. Tyrosine kinase inhibitor sunitinib allows insulin independence in long-standing type 1diabetes. (2014) Diabetes Care 37(5): 87-88.

24. Tyrrell, H.E., Pwint, T. Sunitinib and improved diabetes control. (2014) BMJ Case Rep 24: 2014.

25. Prada, P.O., Ropelle, E.R., Mourão, R.H., et al. EGFR tyrosine kinase inhibitor (PD153035) improves glucose tolerance and insulin action in high-fat diet-fed mice. (2009) Diabetes 58(12): 2910-2919.

26. Lo, H.Y., Hsiang, C.Y., Li, T.C., et al. A novel glycated hemoglobin A1c lowering traditional Chinese medicinal formula, identified by translational medicine study. (2014) PLoS One 9(8): e104650.

27. Lo, H.Y., Ho, T.Y., Lin, C., et al. Momordica charantia and its novel polypeptide regulate glucose homeostasis in mice via binding to insulin receptor. (2013) J Agric Food Chem 61(10): 2461-2468.

28. Zhao, H.L., Sui, Y., Qiao, C.F., et al. Sustained antidiabetic effects of a berberine-containing Chinese herbal medicine through regulation of hepatic gene expression. (2012) Diabetes 61(4): 933-943.

29. Rohrborn, D., Wronkowitz, N., Eckel, J. DPP4 in Diabetes. (2015) Front Immunol 6: 386.

30. Meloni, A.R., DeYoung, M.B., Lowe, C., et al. GLP-1 receptor activated insulin secretion from pancreatic $\beta$-cells: mechanism and glucose dependence. (2013) Diabetes Obes Metab 15(1): 15-27.

31. Drucker, D.J., Nauck, M.A. The incretin system: glucagon-like peptide-1 receptor agonists and dipeptidyl peptidase-4 inhibitors in type 2 diabetes. (2006) Lancet 368(9548): 1696-1705.

32. Hare, K.J., Vilsbøll, T., Asmar, M., et al. The glucagonostatic and insulinotropic effects of glucagon-like peptide 1 contribute equally to its glucose-lowering action. (2010) Diabetes 59(7): 1765-1770.

33. Toft-Nielsen, M.B., Madsbad, S., Holst, J.J. Determinants of the effectiveness of glucagon-like peptide-1 in type 2 diabetes. (2001) J Clin Endocrinol Metab 86(8): 3853-3860.

34. Nauck, M.A., Meier, J.J. Glucagon-like peptide 1 (GLP-1) and its derivatives in the treatment of diabetes. (2005) Regul Pept 128(2): 135-148.

35. Egan, J.M., Bulotta, A., Hui, H., et al. GLP-1receptor agonists are growth and differentiation factors for pancreatic islet beta cells. (2003) Diabetes Metab Res Rev 19(2): 115-123.

36. Stoffers, D.A., Kieffer, T.J., Hussain, M.A., et. al. Insulinotropic glucagon like peptide 1 agonists stimulate expression of homeodomain protein IDX-1 and increase islet size in mouse pancreas. (2000) Diabetes 49(5): 741-748.

37. Marguet, D., Baggio, L., Kobayashi, T., et al. Enhanced insulin secretion and improved glucose tolerance in mice lacking CD26. (2000) Proc Natl Acad Sci USA 97(12): 6874-6879.

38. Conarello, S.L., Li, Z., Ronan, J., et al. Mice lacking Dipeptidyl peptidase IV are protected against obesity and insulin resistance. Proc Natl Acad Sci USA (2003) 100(11): 6825-6830.

39. Ehses, J.A., Casilla, V.R., Doty, T., et al. Glucose-dependent insulinotropic polypeptide promotes beta-(INS-1) cell survival via cyclic adenosine monophosphatemediated caspase-3 inhibition and regulation of p38 mitogen-activated protein kinase. (2003) Endocrinology 144(10): 4433-4445. 40. Trumper, A., Trumper, K., Horsch, D. Mechanisms of mitogenic and antiapoptotic signaling by glucose-dependent insulinotropic polypeptide in beta (INS-1)-cells. (2002) J Endocrinol 174(2): 233-246.

41. Hansotia, T., Baggio, L.L., Delmeire, D., et al. Double incretin receptor knockout (DIRKO) mice reveal an essential role for the enteroinsular axis in transducing the glucoregulatory actions of DPP-IV inhibitors. (2004) Diabetes 53(5): 1326-1335.

42. Zhang, X., Wang, Z., Huang, Y., et al. Effects of chronic administration of alogliptin on the development of diabetes and $\beta$-cell function in high fat diet/streptozotocin diabetic mice. (2011) Diabetes Obes Metab 13(4): 337-347.

43. Ahren, B., Hughes, T.E. Inhibition of dipeptidyl peptidase-4 augments insulin secretion in response to exogenously administered glucagon-like peptide- 1, glucose-dependent insulinotropic polypeptide, pituitary adenylate cyclase-activating polypeptide, and gastrin-releasing peptide in mice. (2005) Endocrinology 146(4): 2055-2059.

44. Dimitriadis, G., Mitrou, P., Lambadiari, V., et al. Insulin effects in muscle and adipose tissue. (2011) Diabetes Res Clin Pract 93(supp 1): $52-59$.

Ommega Online Publishers

Journal Title: Journal of Diabetes and Obesity (JDO)

Journal Short Name: J diabetes Obes
Journal ISSN: 2356-0494

E-mail: diabetes@ommegaonline.com

Website: www.ommegaonline.org 